DOI https://doi.org/10.30525/978-9934-26-007-0-8

\title{
ТЕОРЕТИКО-ПРАВОВІ ПИТАННЯ РОЗВИТКУ ВІЙСЬКОВО-АДМІНІСТРАТИВНОГО ПРАВА В СИСТЕМІ ПРАВА УКРАЇНИ
}

\author{
Діхтієвський П. В., Пашинський В. Й.
}

\section{ВСТУП}

У нинішній складній воєнно-політичній обстановці навколо України, що склалася внаслідок російської збройної агресії, якої Україна зазнала вперше із часів набуття незалежності, окупації й анексії Автономної Республіки Крим, збройного конфлікту на сході України, забезпечення реалізації державою конституційної функції щодо оборони України, захисту ії суверенітету, територіальної цілісності й недоторканності, здійснення публічного управління в такій надзвичайно чутливій сфері, як оборона, є однім з актуальних та складних завдань сьогодення.

Нині проблема забезпечення оборони держави стала однією 3 найбільш пріоритетних у діяльності держави, органів публічного управління, громадянського суспільства та наукової спільноти, потребує подальших наукових досліджень правових аспектів забезпечення оборони. Водночас у вітчизняній юридичній науці проблемам адміністративно-правового забезпечення оборони, з'ясуванню правової природи оборони держави не приділяється належної уваги.

Тому в умовах російської військової агресії, євроатлантичної інтеграції України та проведення оборонної реформи за стандартами НАТО постає необхідність комплексного наукового вирішення теоретичних і практичних питань правового забезпечення оборони держави на основі сучасних розробок юридичної науки. Серед цих проблем важливе місце посідає дискусійне питання щодо галузевої приналежності норм, що регулюють суспільні відносини у сфері оборони, як теоретична основа системного підходу до розвитку військово-адміністративного права і законодавства, адміністративного-правового забезпечення оборони держави й успішного проведення оборонної реформи.

\section{1. Генеза теоретичних поглядів на місце}

\section{військово-адміністративного права в системі права}

Питання щодо галузевої приналежності правових норм, які регулюють суспільні відносини у сфері оборони, має давню історію і дотепер у юридичній науці залишається дискусійним. Зазначена проблема пов'язана з розвитком держави та іï інститутів, насамперед такого державного інституту, як армія (військо), розвитком системи права в конкретний історичний період. 
Протягом століть у суспільстві формувалося ставлення до озброєних людей, збройних формувань, відносин між ними i державою та суспільством. Розвивалася система комплектування, утримання, усебічного забезпечення війська, створювалися ціннісні мотивації для осіб, які виконують специфічні обов'язки військової служби, пов'язані з постійним ризиком для життя. Усе це накопичувалося в суспільній свідомості, психології, традиціях, закріплювалося в різноманітних нормативноправових актах, що регламентували військову справу як специфічну, соціально необхідну та небезпечну сферу людської діяльності.

Суспільна потреба у правовому регулюванні та науковій систематизації питань організації і діяльності війська, порядку комплектування та проходження служби, забезпечення ресурсами, підтримання військової дисципліни, загалом питань правового забезпечення оборони виникла давно в результаті розвитку держави, суспільних відносин у сфері оборони, військової справи і науки.

Ще у Стародавньому Римі, зважаючи на необхідність правової регламентації суспільних відносин у сфері оборони, організації і життя війська, у системі римського права зароджується особлива гілка публічного права - jus militare (мілітарне, або ж військове, право) як сукупність правових норм, що регулюють різні аспекти відносин усередині армії. Значення римського війська як основного інституту держави зумовило розвиток мілітарного (військове) права, яке регулює різні аспекти суспільних відносин усередині армії: питання іiі устрою й організації, комплектування і навчання війська, проходження служби (військова служба була прерогативою вільних громадян) та відставки з військової служби, прав i обов'язків командирів, організації повсякденного життя війська, підтримання військової дисципліни та притягнення до відповідальності, правового статусу вояків ${ }^{1}$.

Подальший розвиток війська, військової справи приводить до появи нових галузей військової науки та навчальних дисциплін, що почали виділятися з воєнної стратегії, як-от: тактика, артилерія, фортифікація та військова адміністрація. На почату ХІХ ст. в Російській імперії, до складу якої тоді входила Україна, виділяється 3 військових наук i починає викладатися навчальна дисципліна - військова адміністрація, предметом якої було вивчення правової природи існування армії, а саме: а) ії устрою й організації; б) поповнення та комплектування; в) проходження служби; г) основ військового управлення; г) забезпечення матеріальних потреб ${ }^{2}$.

\footnotetext{
${ }^{1}$ Підопригора О.А., Харитонов Є.О. Римське право : підручник. 2-ге вид. Київ : Юрінком-Інтер, 2009. 528 c. C. 215 .

2 Лобко П.Л. Записки военной администрации для военных и юнкерских училищ. Санкт-Петербург, 1908. 165 c. C. 5.
} 
На той час у правовій науці питанню стосовно системи національного права не приділялось значної уваги, воно розглядалось переважно побіжно. Право Російської імперії в той період фактично являло собою певний конгломерат правових норм переважно публічно-правової природи, спрямованої на регулювання управлінської діяльності держави у відповідних сферах, які вивчалися в межах науки поліцейського права ${ }^{3}$. У зв'язку із цим питання щодо виділення в системі права військової адміністрації (військово-адміністративне праве) в окрему галузь права не розглядалося.

На початку XX ст., коли розпочинається дискусія про систему галузей права, вчені висловили думку щодо виділення разом із поліцейським інших галузей права, включно з військовим правом. В.М. Гессен поряд з адміністративним (поліцейським) правом визнавав існування судового (цивільний та кримінальний процес), фінансового, міжнародного та військового права ${ }^{4}$.

Водночас військові юристи окреслюють ознаки зародження окремої особливої галузі - військово-адміністративного права. Так, А.М. Добровольський зазначав, що армія у своєму устрої, у внутрішніх відносинах іiі складових частин, підпорядковується нормам права, що визначають устрій армії і всю систему військової організації держави, регулюють весь порядок внутрішнього військового життя. На думку вченого, ці норми у своїй сукупності становлять особливу галузь права, яка, за винятком військовокримінального та військово-судового права, дыстала назву військовоадміністративного права. Військово-адміністративне право - наука про правові норми, що встановлюють устрій, організацію, комплектування армії і забезпечення їі всім необхідним, а також устрій, компетенцію та діяльність органів військової влади 5 .

У середині XX ст. в загальній науковій дискусії про систему радянського права та виділення в ній комплексних галузей стала домінувати концепція теоретичного обгрунтування військового права як комплексної галузі радянської правової системи, що і нині залишається панівною в російській правовій науці. Один із прихильників такого підходу, професор В.М. Чхиквадзе зауважував, що під військовим правом варто розуміти «сукупність військово-юридичних норм, що регулюють відносини, які виникають у сфері устрою, комплектування, життя, побуту та діяльності військ». На його думку, військове право як спеціальна галузь складається з військово-адміністративного, військово-кримінального та військово-

\footnotetext{
${ }^{3}$ Мельник Р.С. Система адміністративного права : дис. ... докт. юрид. наук: 12.00.07. Харків, 2010. 417 с. C. $31-32$.

${ }_{4}^{4}$ Гессен В.М. Лекции по полицейскому праву. Санкт-Петербург : Типография «Съвеър», 1907-1908. 220 c. C. 18.

5 Добровольский А.М. Военно-административное право : Лекции, читанные в 1913-1914 гг. СанктПетербург, 1914. С. 7-8.
} 
судового права. Найбільш широким та об'ємним за своїм змістом у системі військового права $\epsilon$ військово-адміністративне право ${ }^{6}$.

Із 70-х рр. минулого століття концепція військового право як відносно самостійної комплексної галузі права стала панівною в радянській юридичній науці. Так, П.І. Романов у розвиток поглядів своїх попередників запропонував розглядати військове право як комплексну галузь права, як систему встановлених державою правових норм, що закріплюють принципи i форми організації збройних сил, регулюють відносини в галузі їх будівництва, життя, побуту і діяльності, визначають обов'язки, права i відповідальність військовослужбовців та інших учасників військових відносин. Учений підкреслював, що військове право $\epsilon$ комплексним правоутворенням і включає в себе норми різних «традиційних» галузей права (державне, адміністративне, кримінальне, фінансове, земельне й інші), що мають предметну єдність, яка полягає у правовому регулюванні суспільних відносин у галузі військового будівництва у країні ${ }^{7}$.

На думку В.М. Корякіна, військове право - це комплексна галузь права, яка за своєю юридичною природою $є$ впорядкованою сукупністю правових норм, що регулюють суспільні відносини у сфері оборони і військової безпеки держави. Предметом військового права виступають багатоманітні суспільні відносини, які виникають у сфері оборони і військової безпеки. Під військовим правом варто розуміти систему встановлених державою загальнообов'язкових, формально визначених військово-правових норм, що закріплюють форми устрою та принципи функціонування військової організації держави i гарантування ऑiі військової безпеки, які регулюють відносини в галузі будівництва i комплектування збройних сил, інших військ, військових формувань та органів, їхнього матеріально-технічного забезпечення ${ }^{8}$.

Водночас у своїх наукових працях В.М. Корякін визначає військовоадміністративне право / військову адміністрацію як самостійне інституційне утворення у структурі галузі військового права, що виступає відправним поняттям для галузевої юридичної науки та навчальної дисципліни. На його думку, загальним предметом військово-адміністративного права / військової адміністрації є суспільні відносини, що виникають у галузі адміністративних аспектів воєнної діяльності держави, окремих ії інститутів, зокрема й воєнної організації держави. Учений визначає військовоадміністративне право як сукупність правових норм, що регулюють устрій воєнної організації держави, іiі комплектування, повсякденну і бойову

\footnotetext{
${ }^{6}$ Чхиквадзе В.М. Военно-уголовное право. Москва : ВЮА, 1946. Ч. 1 : Общая. 284 с. С. 21-22.

${ }^{7}$ Романов П.И. Военное право как отрасль советского законодательства, учебная и научная дисциплина. Вопросы теории военного законодательства и практики его применения. Москва, 1974. С. $22-43$.

${ }^{8}$ Корякин В.М., Кудашкин А.В., Фатеев К.В. Военно-административное право (военная администрация) : учебник. Москва : За права военнослужащих, 2008. Вып. 90. 496 с. С. 14.
} 
діяльність військ, а також норм, що визначають правове становище органів військового управління і статус військовослужбовців. Він підкреслює тісний зв'язок військової адміністрації з адміністративним правом, для якої вихідними є такі положення, розроблені наукою адміністративного права: загальні принципи державного управління; вчення про законність й особливості іï забезпечення; теоретичні положення про значення державного управління і сутність адміністративно-правових відносин; система i функції органів виконавчої влади; організація державної служби і статус державних службовців; основи адміністративної та дисциплінарної відповідальності громадян 9 .

Можемо констатувати, що вчений фактично розглядає військовоадміністративне право / військову адміністрацію як складову частину системи адміністративного права, яка виступає продовженням і конкретизацію теорії адміністративного права, пов'язана з адміністративним правом як частина із цілим.

Водночас В.М. Корякін погоджується з думкою тих учених, які вважають, що неправильно розглядати військову адміністрацію як підгалузь науки адміністративного права. 3 цієї ж причини, значною мірою, військова адміністрація не може іменуватися військово-адміністративним правом ${ }^{10}$.

Отже, у радянській юридичній науці сформувалася концепція щодо розуміння військового права як комплексної галузі права, незважаючи на те, що питання можливості формування комплексних галузей права залишається предметом наукових дискусій. Водночас учені, які розглядали військове право як комплексну галузь права, у системі цього правового утворення визнавали провідну роль військово-адміністративного права.

\section{2. Теоретичні підходи до формування військово-адміністративного права у вітчизняній юридичній науці}

У цьому дослідженні ми свідомо значну увагу приділяємо питанням історичного розвитку теоретичних поглядів на місце військово-адміністративного права в системі права загалом i адміністративного права безпосередньо, тому що радянська концепція системи права, зокрема й адміністративного, має певну підтримку і серед українських учених.

Але навіть за наявності невеликої кількості наукових праць в українській юридичній науці, у яких досліджуються правові аспекти забезпечення оборони держави, натепер серед українських учених-юристів існують різні підходи до визначення галузевої приналежності правових норм, що

\footnotetext{
${ }^{9}$ Корякин В.М., Кудашкин А.В., Фатеев К.В. Военно-административное право (военная администрация) : учебник. Москва : За права военнослужащих, 2008. Вып. 90.496 с. С. 18

${ }^{10}$ Военная администрация : учебник / под ред. П.И. Романова. Москва : Изд-во ВПА, 1970. 466 с. С. 11.
} 
регулюють суспільні відносини у сфері оборони та воєнної безпеки держави, місця цих правових утворень у системі українського права.

Так, П.П. Богуцький, О.В. Кривенко, I.I. Качан ${ }^{11}$ дотримуються наукових поглядів, що домінували за радянських часів, що суспільні відносини у сфері оборони держави регулюються нормами права, які утворюють комплексну галузь права - військове право. П.П. Богуцький уважає, що військове право $\epsilon$ комплексною галуззю права - системою загальнообов'язкових норм, формально визначених правил поведінки у військовопублічній сфері, які встановлені, охороняються та забезпечуються державою, здійснюють регулювання суспільних відносин, пов'язаних із діяльністю воєнної організації суспільства, і мають за мету забезпечення захисту держави, іï суверенітету, територіальної цілісності ${ }^{12}$.

У системі військового права як комплексній галузі права він виділяє такі підгалузі: право військової безпеки й оборони; право проходження військової служби; військово-соціальне право; військово-господарське право; військово-кримінальне право та військово-адміністративне право ${ }^{13}$.

У системі військово-адміністративного права, яке, на його думку, $є$ підгалуззю військового права, виокремлюють такі правові інститути: інститут права управління військовими формуваннями; інститут права гарнізонної служби; інститут права внутрішньої служби; інститут права військової служби правопорядку; інститут права адміністративної відповідальності військовослужбовців ${ }^{14}$.

Варто наголосити, що, на наше переконання, коло суспільних відносин та правових норм, які регулюють ці відносини й утворюють відповідні інститути військово-адміністративного права, $є$ набагато ширшим, а визначені підгалузі військового права насправді належать до військово-адміністративного права. Так, наприклад, вони вважають, що до підгалузі «Право проходження військової служби» належать: інститут права комплектування військових формувань; інститут права підготовки до військової служби; інститут права приписки громадян до призовних дільниць; інститут права проходження військової служби; інститут військово-дисциплінарного права; інститут права проходження служби у військовому резерві; інститут права виконання військового обов'язку в запасі.

\footnotetext{
11 Богуцький П.П. Військове право України: джерела, структура та розвиток : монографія. Одеса : Фенікс, 2008. 188 с. ; Кривенко О.В., Качан I.I. Військова адміністрація (право військової сфери у визначеннях та схемах) : навчальний посібник. 2-ге вид., переробл. і доповн. Київ, 2010. 196 с.

12 Богуцький П.П. Військове право у системі права України : дис. ... канд. юрид. наук: 12.00.01. Одеса, 2008. 216 c. C. 68.

${ }^{13}$ Там само. С. 70.

${ }^{14}$ Кривенко О.В., Качан I.I. Військова адміністрація (право військової сфери у визначеннях та схемах) : навчальний посібник. 2-ге вид, переробл. і доповн. Київ, 2010. 196 с. С. 4 ; Богуцький П.П. Військове право України: джерела, структура та розвиток : монографія. Одеса : Фенікс, 2008. 188 с. С. 125.
} 
Ми не поділяємо таку думку вчених. На наш погляд, суспільні відносини щодо виконання громадянами військового обов'язку та проходження військової служби регулюються правовими нормами, які належать до норм адміністративного права. Ці правовідносини по своїй суті є відносинами між суб'єктами публічної адміністрації та громадянами щодо забезпечення публічного інтересу, а саме: прав і законних інтересів людини, суспільства і держави від загроз застосування збройної сили, і за своєю юридичною природою $\epsilon$ адміністративно-правовими відносинами, що регулюються нормами адміністративного права ${ }^{15}$.

Варто зазначити, що серед українських учених поширені й інші погляди щодо галузевої приналежності правових норм, які регулюють суспільні відносини у сфері оборони держави. Так, автори навчального посібника «Військова адміністрація» зазначають, що військова адміністрація пов'язана 3 галузевими правовими науками та галузями права. Але найтісніший зв'язок військова адміністрація має з адміністративним правом, виступає як органічна частина адміністративного права. Базовими для військової адміністрації є положення адміністративного права, що стосуються загальних принципів державного управління, функцій, форм та методів державного управління, забезпечення законності, правопорядку і дисципліни в державному управлінні, питань адміністративної та дисциплінарної відповідальності за вчинення правопорушень ${ }^{16}$.

На підтвердження своєї позиції наведемо думку вчених, які вважають, що загальним предметом військово-адміністративного права $є$ суспільні відносини, що виникають у галузі адміністративних аспектів військової діяльності держави та їі інститутів. У військово-адміністративному предметі виділяють декілька груп однорідних суспільних відносин у сфері гарантування військової безпеки й оборони держави.

До першої групи належать суспільні відносини у сфері організаційного забезпечення військової безпеки й оборони держави, діяльності всіх суб'єктів забезпечення оборони, підготовки до оборони та застосування із цією метою всіх складових частин військової організації (сектор безпеки й оборони) держави; військового будівництва; управління військовою організацією держави та іiі всебічного забезпечення; до другої групи належать суспільні відносини, пов'язані 3 виконанням громадянами військового обов'язку, вступом на військову службу за контрактом, проходженням військової служби, проходженням військової служби в резерві та за призовом за мобілізацією, а також із реалізацією правового

\footnotetext{
${ }^{15}$ Пашинський В.Й. Військово-адміністративне право в системі сучасного адміністративного права. Адміністративне право і проџес. 2017. № 2 (20). С. 40-49.

16 Тищенко М.М., Богуцький В.В., Григоренко Є.І. Військова адміністрація : навчальний посібник / за заг. ред. М.М. Тищенка. Харків : Право, 2013. 304 с. С. 31.
} 
статусу військовослужбовців та забезпечення їхнього соціального захисту; до третьої групи - відносини, пов'язані 3 підтриманням військової дисципліни, законності і правопорядку, притягненням військовослужбовців до юридичної відповідальності, діяльністю органів військової юстиції та військових правоохоронних органів; до четвертої групи - суспільні відносини, що виникають у процесі збройного конфлікту і стосуються правових аспектів оперативно-тактичного управління військами під час ведення бойових дій ${ }^{17}$.

На думку сучасних українських учених-адміністративістів, відповідно до запропонованої ними концепції системи адміністративного права, уся сукупність норм адміністративного права поділяється на загальні й особливі норми адміністративного права, які утворюють, відповідно, Загальне адміністративне право й Особливе адміністративне право ${ }^{18}$.

Загальне адміністративне право складається 3 інститутів адміністративного права: принципів адміністративного права; джерел адміністративного права; суб'єктів публічної адміністрації суб'єктивних публічних прав приватних осіб; адміністративних актів публічної адміністрації; публічного майна; позасудового захисту прав і свобод приватних осіб, порушених суб'єктами публічної адміністрації ${ }^{19}$.

Особливе адміністративне право, що формується у процесі трансформації Особливої частини українського адміністративного права, утворюють норми, які регулюють засади реалізації публічного управління в окремих сферах: управління внутрішніми справами, управління юстицією, управління національною безпекою, управління обороною ${ }^{20}$.

Отже, з поглядів сучасної адміністративно-правової науки, що грунтуються на європейських підходах до системи адміністративного права, норми адміністративного права, через які здійснюється регулювання суспільних відносин у відповідних сферах взаємодії публічної адміністрації та приватних осіб, утворюють окремі підгалузі, що формують систему Особливого адміністративного права.

Система Особливого адміністративного права має будуватися відповідно до напрямів діяльності публічної адміністрації, що зазначені в Конституції України та визначають перелік обов'язків (функцій) публічної адміністрації. Порядок реалізації кожної з таких функцій, а отже, регулювання відносин,

\footnotetext{
${ }^{17}$ Корякин В.М., Кудашкин А.В., Фатеев К.В. Военно-административное право (военная администрация) : учебник. Москва : За права военнослужащих, 2008. Вып. 90. 496 с. С. 16.

18 Загальне адміністративне право : підручник / І.С. Гриценко та ін. ; за заг. ред. І.С. Гриценка. Київ : Юрінком-Інтер, 2015. 568 с. С. 71.

${ }^{19}$ Там само. С. 72.

${ }^{20}$ Колпаков В.К., Кузьменко О.В. Адміністративне право України : підручник. Київ : Юрінком-Інтер, 2003. 544 c. C. 18.
} 
що будуть виникати в цій сфері між публічною адміністрацією та приватними особами, відносин усередині публічної адміністрації, а також між останньою й іншими суб'єктами публічного права має здійснюватися за допомогою окремої підгалузі Особливого адміністративного права ${ }^{21}$. У такому разі Особливе адміністративне право набуває значення поліструктурного правового утворення, яке починає регулювати адміністративно-правові відносини, що виникають між публічною адміністрацією та приватними особами в чітко визначених сферах ${ }^{22}$, серед яких однією зголовних виступає сфера оборони держави як функція, визначена Конституцією України.

Ця концепція знайшла підтвердження в наукових працях українських учених-адміністративістів, які доводять існування в межах Особливого адміністративного права як складного поліструктурного правового утворення різних галузей та підгалузей права: адміністративного процедурного права, адміністративно-господарського права, адміністративно-спортивного права, міграційного права тощо.

Підтримуємо зазначену концепцію щодо системи адміністративного права та пропозиції стосовно виділення в межах Особливого адміністративного права, яке $є$ поліструктурним правовим утворенням, базових або основних підгалузей, необхідність існування яких зумовлена вимогами Конституції України і до яких відносять адміністративно-господарське, муніципальне, поліцейське, службове, соціальне, адміністративно-культурне, адміністративно-деліктне, адміністративно-будівельне, адміністративно-телекомунікаційне, атомне право, право соціального забезпечення, право охорони навколишнього природного середовища, i вважаємо за необхідне висловити свою думку.

Натепер перелік підгалузей Особливого адміністративного права $\epsilon$ відкритим і залежить від функцій, які реалізує публічна адміністрація ${ }^{23}$ в конкретних історичних умовах розвитку держави. Водночас однією 3 основних функцій держави, визначених Конституцією України (ст. 17), є оборона України, захист їі суверенітету й територіальної цілісності, яка також визнається справою всього українського народу, тобто суспільства ${ }^{24}$.

Саме тому реалізація передбачених Конституцію України обов'язків (функції) публічної адміністрації щодо забезпечення оборони держави

\footnotetext{
${ }^{21}$ Мельник Р.С. Система адміністративного права : дис. ... докт. юрид. наук: 12.00.07. Харків, 2010. 417 с. С. 332-333 ; Мельник Р.С. Система адміністративного права України : монографія. Харків : Вид-во Харк. нац. ун-ту внутр. справ, 2010. 398 с. С. 327-328.

${ }_{22}^{2}$ Мельник Р.С. Система адміністративного права : дис. ... докт. юрид. наук: 12.00.07. Харків, 2010. 417 с. C. 326.

${ }^{23}$ Там само. С. 325.

24 Конституція України. URL: http://zakon2.rada.gov.ua/laws/show/254\%D0\%BA/96-\%D0\%B2\%D1\%80 (дата звернення: 05.09.2018).
} 
та регулювання суспільних відносин, які виникають у сфері оборони держави між органами публічного управління та приватними особами, іншими суб'єктами публічного права, має здійснюватися в межах окремої підгалузі Особливого адміністративного права - військово-адміністративного права.

Необхідно зазначити, що розвиток і виділення в системі права нових галузей / підгалузей права пов'язаний 3 розвитком та диференціацією суспільних відносин у різних сферах життя українського суспільства й держави, виникненням нових об'єктів правового регулювання, розвитком спеціального законодавства тощо.

Нинішні докорінні зміни, що відбуваються в усіх сферах суспільного життя (політична, економічна, соціальна, культурна, безпекова, оборонна) нашої держави, зумовлені європейським вектором розвитку, впливають на розвиток системи права. Активний розвиток суспільних відносин у сфері оборони держави безпосередньо впливає на розвиток системи адміністративного права, формування в межах Особливого адміністративного права підгалузі військово-адміністративного права, яка регулює сферу оборони.

Отже, зважаючи на результати сучасних наукових досліджень вітчизняних учених-адміністративістів щодо системи адміністративного права та сучасних тенденцій iї розвитку, в умовах активного розвитку суспільних відносин у сфері оборони, що зумовлено фактичним веденням воєнних дій, необхідністю проведення оборонної реформи для забезпечення оборони, захисту суверенітету і територіальної цілісності України, доцільно розглядати питання щодо формування такої підгалузі Особливого адміністративного права, як військово-адміністративне право ${ }^{25}$.

Предметом правового регулювання військово-адміністративного права $\epsilon$ суспільні відносин, які виникають між публічною адміністрацією та приватними особами, відносини в публічній адміністрації, зокрема й в органах військового управління та військового командування, а також між останньою й іншими суб'єктами публічного права в різних сферах суспільного життя, спрямовані на забезпечення оборони держави України.

\section{ВИСНОВКИ}

Питання щодо галузевої приналежності правових норм, які регулюють суспільні відносини у сфері оборони, нерозривно пов'язане з розвитком держави та її інститутів, передусім такого державного інституту, як армія (військо), розвитком системи права в конкретний історичний період.

Суспільна потреба у правовому регулюванні та науковій систематизації питань організації і діяльності війська, порядку комплектування та

\footnotetext{
${ }^{25}$ Пашинський В.Й. Забезпечення оборони України: адміністративно-правові аспекти : монографія. Київ, 2018. 408 с. С. 93.
} 
проходження служби, забезпечення ресурсами, підтримання військової дисципліни, загалом питань забезпечення оборони виникла в результаті розвитку держави, суспільних відносин у сфері оборони, військової справи і науки.

У радянській юридичній науці сформувався концепція, що суспільні відносини у сфері оборони регулюються нормами військового права, яке $\epsilon$ комплексною галуззю права та включає військово-кримінальне, військовосудове та військово-адміністративне право. Прихильники такої концепції в системі військового права як комплексній галузі права визнавали провідну роль військово-адміністративного права.

У вітчизняній юридичній науці існує два концептуальні підходи щодо галузевої приналежності правових норм, які регулюють суспільні відносини у сфері оборони. Прихильники першого підходу дотримуються наукових поглядів, які домінували 3 радянських часів, що суспільні відносини усфері оборони держави регулюються нормами права, які утворюють комплексну галузь - військове право. Прихильники іншого підходу вважають, що суспільні відносини у сфері оборони держави регулюються нормами військово-адміністративного права, яке є підгалуззю Особливого адміністративного права.

Зважаючи на сучасні наукові підходи і тенденції розвитку системи національного адміністративного права, на активний розвиток суспільних відносин у сфері оборони, зумовлений фактичним веденням воєнних дій, необхідністю проведення оборонної реформи для забезпечення оборони, захисту суверенітету і територіальної цілісності України, доцільно розглядати питання формування в межах Особливого адміністративного права окремої підгалузі - військово-адміністративного права, норми якого регулюють суспільні відносини у сфері оборони держави.

Предметом правового регулювання військово-адміністративного права виступають суспільні відносини, які виникають між органами публічного управління та приватними особами, відносини всередині органів публічного управління, а також між органами публічного управління й іншими суб'єктами публічного права, у різних сферах суспільного життя, спрямовані на забезпечення оборони держави України.

Виділення військово-адміністративного права як самостійного інституційного утворення, самостійної підгалузі в системі Особливого адміністративного права сприятиме розвитку правової науки та системи національного права, включно із системою національного адміністративного права, iï адаптації до стандартів європейської правової теорії та європейського законодавства, покращенню правотворчої діяльності та систематизації законодавства у сфері оборони. 


\section{АНОТАЦІЯ}

Дослідження присвячене розвитку теоретичних підходів до місця в системі адміністративного права правових норм, що регулюють суспільні відносини у сфері оборони держави. Обгрунтовується формування в системі сучасного адміністративного права військово-адміністративного права як підгалузі Особливого адміністративного права.

Питання щодо галузевої приналежності правових норм, які регулюють суспільні відносини у сфері оборони, нерозривно пов'язане з розвитком держави та іiі інститутів, насамперед такого державного інституту, як армія (військо), розвитком системи права в конкретний історичний період.

Суспільна потреба у правовому регулюванні та науковій систематизації питань організації і діяльності війська, порядку комплектування та проходження служби, забезпечення ресурсами, підтримання військової дисципліни, загалом питань забезпечення оборони виникла в результаті розвитку держави, суспільних відносин у сфері оборони, військової справи і науки.

Ще у Стародавньому Римі, зважаючи на необхідність правової регламентації суспільних відносин у сфері оборони, організації і життя війська, у системі римського права зароджується особлива гілка публічного права - jus militare (мілітарне, або ж військове, право) як сукупність правових норм, що регулюють різні аспекти відносин усередині армії.

У радянській юридичній науці сформувалася концепція, що суспільні відносини у сфері оборони регулюються нормами військового права, яке $\epsilon$ комплексною галуззю права та включає військово-кримінальне, військовосудове та військово-адміністративне право. Прихильники такої концепції в системі військового права як комплексній галузі права визнавали провідну роль військово-адміністративного права.

У вітчизняній юридичній науці існує два концептуальні підходи щодо галузевої приналежності правових норм, які регулюють суспільні відносини у сфері оборони. Прихильники першого підходу дотримуються наукових поглядів, які домінували 3 радянських часів, що суспільні відносини у сфері оборони держави регулюються нормами права, які утворюють комплексну галузь - військове право. Прихильники іншого підходу вважають, що суспільні відносини у сфері оборони держави регулюються нормами військово-адміністративного права. яке є підгалуззю Особливого адміністративного права.

Зважаючи на сучасні наукові підходи та тенденції розвитку системи національного адміністративного права, на активний розвиток суспільних відносин у сфері оборони, зумовлений фактичним веденням воєнних дій, необхідністю проведення оборонної реформи для забезпечення оборони, 
захисту суверенітету i територіальної цілісності України, доцільно розглядати питання формування в межах Особливого адміністративного права окремої підгалузі - військово-адміністративного права, норми якого регулюють суспільні відносини у сфері оборони держави.

\section{ЛІТЕРАТУРА}

1. Підопригора О.А., Харитонов С.О. Римське право : підручник. 2-ге вид. Київ : Юрінком-Інтер, 2009. 528 с.

2. Лобко П.Л. Записки военной администрации для военных и юнкерских училищ. Санкт-Петербург, 1908. 165 с.

3. Мельник Р.С. Система адміністративного права : дис. ... докт. юрид. наук: 12.00.07. Харків, 2010. $417 \mathrm{c}$.

4. Гессен В.М. Лекции по полицейскому праву. Санкт-Петербург : Типография «Съвеьр», 1907-1908. 220 с.

5. Добровольский А.М. Военно-административное право : Лекции, читанные в 1913-1914 гг. Санкт-Петербург, 1914. 187 с.

6. Чхиквадзе В.М. Военно-уголовное право. Москва: ВЮА, 1946. Ч. 1 : Общая. 284 c.

7. Романов П.И. Военное право как отрасль советского законодательства, учебная и научная дисциплина. Bопросы теории военного законодательства и практики его применения. Москва, 1974. С. 22-43

8. Корякин В.М., Кудашкин А.В., Фатєєв К.В. Военно-административное право (военная администрация) : учебник. Москва : За права военнослужащих, 2008. 496 с.

9. Военная администрация : учебник / под ред. П.И. Романова. Москва : Изд-во ВПА, 1970. 466 с.

10. Богуцький П.П. Військове право України: джерела, структура та розвиток : монографія. Одеса : Фенікс, 2008. 188 с.

11. Кривенко О.В., Качан I.I. Військова адміністрація (право військової сфери у визначеннях та схемах) : навчальний посібник. 2-ге вид., переробл. і доповн. Київ, 2010. 196 с.

12. Богуцький П.П. Військове право у системі права України : дис. ... канд. юрид. наук: 12.00.01. Одеса, 2008. 216 с. С. 68.

13. Пашинський В.Й. Військово-адміністративне право в системі сучасного адміністративного права. Адміністративне право і процес. 2017. № 2 (20). С. 40-49.

14. Тищенко М.M., Богуцький В.В., Григоренко С.I. Військова адміністрація : навчальний посібник ; за заг. ред. М.М. Тищенка. Харків : Право, 2013. 304 с. 
15. Загальне адміністративне право : підручник / I.C. Гриценко та ін. ; за заг. ред. І.С. Гриценка. Київ : Юрінком-Інтер, 2015. 568 с.

16. Колпаков В.К., Кузьменко О.В. Адміністративне право України : підручник. Київ : Юрінком-Інтер, 2003. 544 с.

17. Мельник Р.С. Система адміністративного права України : монографія. Харків : Вид-во Харк. нац. ун-ту внутр. справ, 2010. 398 с.

18. Конституція України. URL: http://zakon2.rada.gov.ua/laws/show/ 254\%D0\%BA/96-\%D0\%B2\%D1\%80 (дата звернення: 05.09.2018).

19. Пашинський В.Й. Забезпечення оборони України: адміністративноправові аспекти : монографія. Київ, 2018. 408 с.

\section{Information about authors:} Dikhtievskiy P. V.,

Doctor of Law, Professor, Head of the Department of Administrative Law and Procedure Institute of Law of Taras Shevchenko National University of Kyiv 60, Volodymyrivska str., Kyiv, 01601, Ukraine

Pashinskiy V. Y.,

Candidate of Law, Associate Professor, Associate Professor at the Department of Administrative Law and Procedure Institute of Law of Taras Shevchenko National University of Kyiv 60, Volodymyrivska str., Kyiv, 01601, Ukraine 